Open Access

\title{
Erratum to: Analysis of velocity-mapped ion images from high-resolution crossed-beam scattering experiments: a tutorial review
}

Alexander von Zastrow, Jolijn Onvlee, David H. Parker and Sebastiaan YT van de Meerakker ${ }^{*}$

* Correspondence: basvdm@science.ru.nl

Radboud University, Institute for Molecules and Materials,

Heijendaalseweg 135, Nijmegen

6525 AJ, Netherlands

\section{Erratum}

Unfortunately, the original version of this article [1] contained an error. The DOI was included incorrectly in the PDF version of the file. The DOI has now been corrected in the original PDF and is also included correctly below:

Correct article DOI - 10.1140/epjti/s40485-015-0020-z.

Received: 24 September 2015 Accepted: 24 September 2015

Published online: 02 November 2015

Reference

1. Zastrow $V$ et al. Analysis of velocity-mapped ion images from high-resolution crossed-beam scattering experiments: a tutorial review. EPJ Tech Instrum. 2015;2:11.
Submit your manuscript to a SpringerOpen ${ }^{\circ}$ journal and benefit from:

- Convenient online submission

Rigorous peer review

Immediate publication on acceptance

- Open access: articles freely available online

- High visibility within the field

Retaining the copyright to your article

Submit your next manuscript at $\boldsymbol{\wedge}$ springeropen.com 